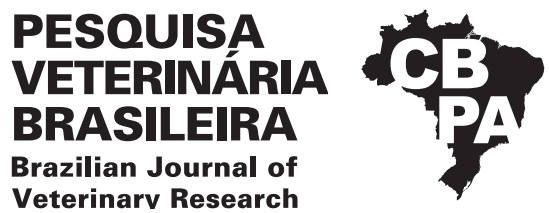

Pesq. Vet. Bras. 40(6):426-429, June 2020 DOI: 10.1590/1678-5150-PVB- 6636

Original Article

arv Research

Livestock Diseases

ISSN 0100-736X (Print)

(cc) BY-NC

ISSN 1678-5150 (Online)

\title{
Arthrogryposis multiplex congenita in Aberdeen Angus cattle in Uruguay ${ }^{1}$
}

\author{
Agustín Romero*2 (D), Carolina Briano $^{2}$ and Fernando Dutra Quintela ${ }^{2}$
}

\begin{abstract}
Romero A., Briano C. \& Dutra F. 2020. Arthrogryposis multiplex congenita in Aberdeen Angus cattle in Uruguay. Pesquisa Veterinária Brasileira 40(6):426-429. División de Laboratorios Veterinarios "Miguel C. Rubino", Laboratorio Regional Este, Avelino Miranda 2045, CP 33000, Treinta y Tres, Uruguay. E-mail: aromero@mgap.gub.uy

Arthrogryposis multiplex congenita is reported for the first time in the Aberdeen Angus (AA) breed in Uruguay. In a commercial herd of 30 purebred Aberdeen Angus cows, two calves with severe musculoskeletal malformations died at birth. The cows had been inseminated using semen imported from Argentina from one elite AA sire only. At necropsy, one calf showed severe muscular atrophy, arthrogryposis affecting all four limbs and the spine, kyphoscoliosis and torticollis. Histopathology showed muscular atrophy with marked fiber size variation and abundant fibroadipose fibers. The central nervous system only showed congestion and edema due to dystocia, whereas the peripheral nerves and the number of motor neurons in the spinal appeared normal. DNA analysis confirmed arthrogryposis multiplex congenita. It is concluded that disease in Aberdeen Angus cattle is due to failure in the neuromuscular junction.
\end{abstract}

INDEX TERMS: Arthrogryposis multiplex congenita, bovine, Aberdeen Angus, cattle, Uruguay, hereditary diseases.

\begin{abstract}
RESUMO.- [Artrogripose múltipla congênita em bovinos Aberdeen Angus no Uruguai.] Artrogripose múltipla congênita é relatada pela primeira vez em bovinos Aberdeen Angus (AA) no Uruguai. Num rebanho comercial de 30 vacas a Aberdeen Angus, dois bezerros com graves malformações musculoesqueléticas morreram logo após o nascimento. As vacas foram inseminadas utilizando sêmen importado da Argentina, de apenas um touro de elite de AA. Na necropsia, um dos bezerros apresentava atrofia muscular grave, artrogripose afetando todos os quatro membros e a coluna vertebral, cifoscoliose e torcicolo. A histopatologia demonstrou atrofia muscular com acentuadas variações no tamanho das fibras e abundantes fibras fibroadiposas. 0 sistema nervoso central apresentava apenas congestão e edema devido à distocia, enquanto os nervos periféricos e o número de neurônios motores na medula espinhal pareciam normais. A análise de DNA confirmou artrogripose múltipla congênita. Concluiu-se que a doença em bovinos Aberdeen Angus se deve a falha na junção neuromuscular.
\end{abstract}

TERMOS DE INDEXAÇÃO: Artrogripose múltipla congênita, bovinos, Aberdeen Angus, Uruguai, doenças hereditárias.

\footnotetext{
${ }^{1}$ Received on March 18, 2020.

Accepted for publication on April 2, 2020.

${ }^{2}$ División de Laboratorios Veterinarios (DILAVE) "Miguel C. Rubino", Laboratorio Regional Este, Avelino Miranda 2045, CP 33000, Treinta y Tres, Uruguay. *Corresponding author: aromero@mgap.gub.uy
}

\section{INTRODUCTION}

Hereditary diseases in cattle are a cause of growing concern worldwide. The use of artificial insemination, multiple ovulation embryo transfer, and international trade in germplasm have led to the propagation of economically valuable productive features, but also some defective recessive genes, with significant impact on fertility and animal health (Windsor \& Agerholm 2009, Windsor et al. 2011). Modern breeding in cattle has caused the simultaneous appearance of inherited disorders in many countries (Charlier et al. 2008, Windsor \& Agerholm 2009, Jolly \& Windsor 2010, Windsor et al. 2011), including Uruguay (Kelly et al. 2012, Dutra et al. 2017). Diseases such as osteopetrosis and neuropathic hydrocephalus in Aberdeen Angus (AA) breed and cardiomyopathy wooly haircoat and maple syrup urine disease (MSUD) in Hereford and Polled Hereford (HR) breeds are examples of this (Windsor et al. 2011, Dutra et al. 2011, 2015).

In Uruguay, commercial beef cattle production is unique because it is mostly performed using purebreds, mainly HR and AA, with limited use of crossbreeding systems (DIEA 2003). It is also common to import germplasm from a few genetic lines for use in commercial and elite herds (Dutra 2016).

Arthrogryposis (crooked joints) is a congenital malformation characterized by curvature of the extremities, multiple joint stiffness, and muscular dysplasia, and is reported in different dairy and beef cattle breeds, such as HR, AA, Charolais, 
Shorthorn, Jersey, Holstein-Friesian and Red Danish (Shupe et al. 1967, Windsor et al. 2011, Agerholm et al. 2016, Craig et al. 2016). Arthrogryposis multiplex congenita (AMC; OMIA 2020, 002135-9913, commonly known as curly calf syndrome) is a lethal autosomal recessive genetic disorder of AA, originating in the bull Rito 9J9 of B156 7T26 and distributed widely through the bull GAR Precision 1680 (Kaiser 2009, Whitlock 2010, Windsor et al. 2011). The disease in AA has been confirmed in North America (Beever \& Marron 2011) and Australia (Windsor et al. 2011) only. Affected animals have severe contraction of the joints in limbs, neck, and spine and are born dead or die shortly after birth; however, there may also be embryonic and fetal losses. Calves have a significantly lower weight $(15-25 \mathrm{~kg})$ due to poor muscular development (Windsor et al.2011, Cooper \& Valentine 2016). The forelimbs are normally in fixed flexion and hindlimbs can be fixed in flexion or extension, with deviation of the spine and facial bones. In some cases, cleft palate, mild hydrocephalus and abnormalities of the ribs and sternum have been observed (Agerholm et al. 2016), but no histological findings have been reported. The disease is due to a deletion of 23,363 bp that cover three different genes: ISG15, HES4 and AGRN (Beever \& Marron 2011). The AGRN gene encodes for agrin, identified as an essential neural regulator that induces the aggregation of acetylcholine receptors (AChRs) and other postsynaptic proteins on muscle fibers and is crucial for the formation and maintenance of the neuromuscular junction (NMJ) (Burgess et al. 1999, Maselli et al. 2012).

This study reports the macroscopic and histological examination of two Aberdeen Angus calves with arthrogryposis multiplex congenita, subsequently confirmed by molecular analysis.

\section{MATERIALS AND METHODS}

The pathological diagnosis was made at the "Laboratorio Regional Este" of the "División de Laboratorios Veterinarios (DILAVE) Miguel C. Rubino", Treinta y Tres, Uruguay. A complete post-mortem examination, including the central nervous system and the skeleton, was performed in the affected calves. The entire brain and spinal cord, and samples of fore and hindlimb muscles and several organs were fixed in $10 \%$ neutral buffered formalin, embedded in paraffin, sectioned at $5-7 \mu \mathrm{m}$ and stained with hematoxylin and eosin (HE), phosphotungstic acid hematoxylin (PTAH) and Masson's trichrome (MT).

Blood clots and spleen samples were collected and stored at $-20^{\circ} \mathrm{C}$ until genomic DNA extraction. The extraction of genomic DNA was carried out using commercial DNA extraction kits (MagMAX ${ }^{\mathrm{TM}}$ 96DNA Multi-Sample Kit). Samples were submitted to a commercial laboratory (Neogen GeneSeek, Lincoln/NE, USA) for genotyping using the AM2 test, which detects the mutation response of AMC. This test uses Illumina Infinium chemistry.

\section{RESULTS}

The disease was observed in a herd of 30 pregnant purebred AA adult cows in the Department of Rocha, Uruguay, during September 2017. Two calves with severe malformations that required cesarean section died at birth. The cows had been inseminated using semen imported from Argentina from one elite AA sire only. No cases or fetal losses were detected previously in the affected cows.

Post-mortem examination of two affected calves showed full-term animals with low body weight, arthrogryposis, kyphoscoliosis and torticollis. In both animals, the forelimbs were curled in flexion and the hindlimbs in extension (Fig.1). After opening, all distal and proximal limb joints allowed free flexion and extension motion, thus showing the absence of ankylosis. There was lateral deviation of the head and severe scoliosis, with deviation of the cervical, thoracic and lumbar vertebral column and deformation of the rib cage and sternum in Calf No. 2 (Fig.2). Internal organ lesions were mostly associated with the narrowing of the body cavities. The lung was compressed and had fetal atelectasis. Grossly, the brain was very congestive and on the cut surface the gray cortex appeared pale and the subcortical white matter hyperemic ("ribbon effect"), indicating birth asphyxia (Dutra et al. 2007). The entire spinal cord was macroscopically normal. All the muscles of the carcass were severely atrophic, pale and sticky in texture. In Calf No. 2, both hip joints were abnormally shaped and partially dislocated. No lesions were found in the bones, including growth plates, epiphysis and bone marrow.

Histologically, the skeletal muscles were largely replaced by fibrofatty connective tissue with a severe lack of myofibers. The few remnant muscle fibers exhibited variation in diameter with many atrophic fibers that appeared rounded instead of polygonal and abundant endomysial and perimysial connective tissue. MT staining showed predominantly collagen fibers and

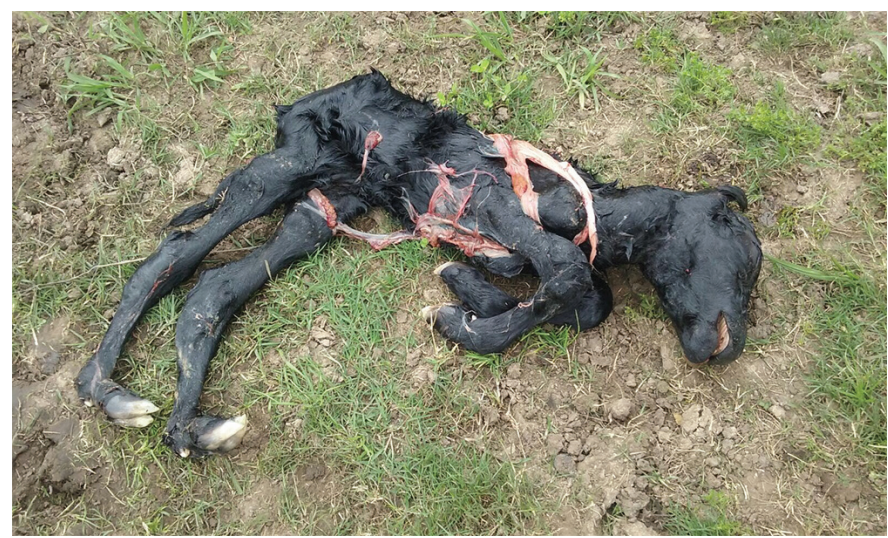

Fig.1. Arthrogryposis multiplex congenita in Calf No.1. Note contracted forelimbs, extended rear limbs, curved neck and the very thin appearance due to reduced muscle development.

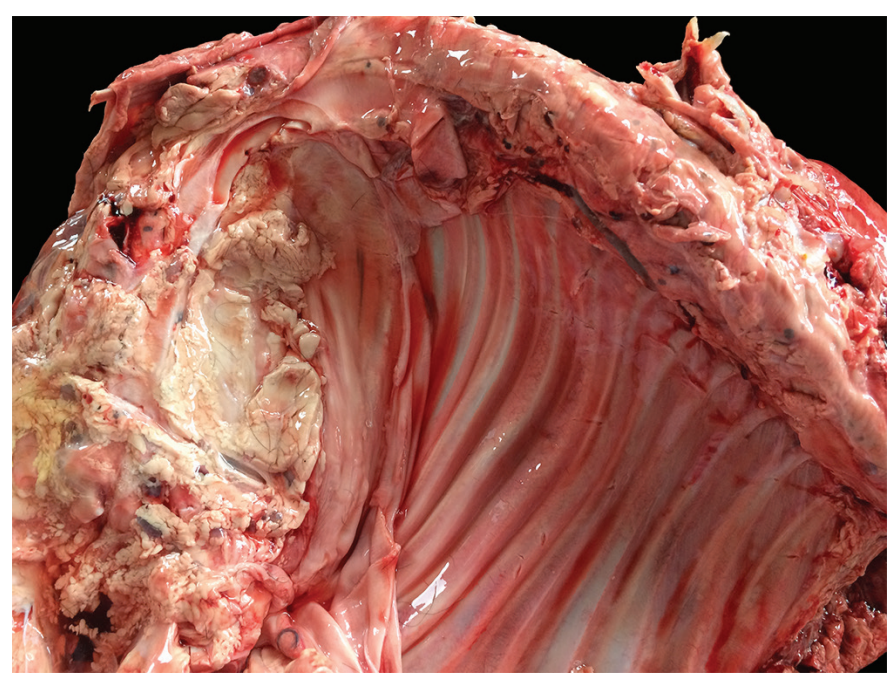

Fig.2. Arthrogryposis multiplex congenita in Calf No. 2. Note the severely curved thoracolumbar spine and deformed rib cage. 
muscular hypoplasia at the skeletal muscle level (Fig.3), and with PTAH staining the fibers appeared smooth and faint, and cross striations were apparent (Fig.4). Intramuscular nerves containing myelinated and Schwann cells in normal proportions were apparent (Fig.5). The brain had marked congestion of the gray cortex and subcortical white matter, thoracic and lumbar spinal cord was normal, with the cytomorphology and number of spinal ventral motor neurons within the normal range. The rest of the organs stained with HE were normal.

The homozygous mutation responsible for AMC (AM-Affected) was confirmed by genotyping (AM2 test - NEOGEN). The SNP Call Rate was 0.9618, ensuring a high-confidence genotype.

\section{DISCUSSION}

Arthrogryposis can be caused by teratogenic viruses, toxic plants, and hereditary diseases (Agerholm et al. 2015, Craig et al. 2016). During early embryogenesis, movement is essential for the development of joints and skeletal muscles,

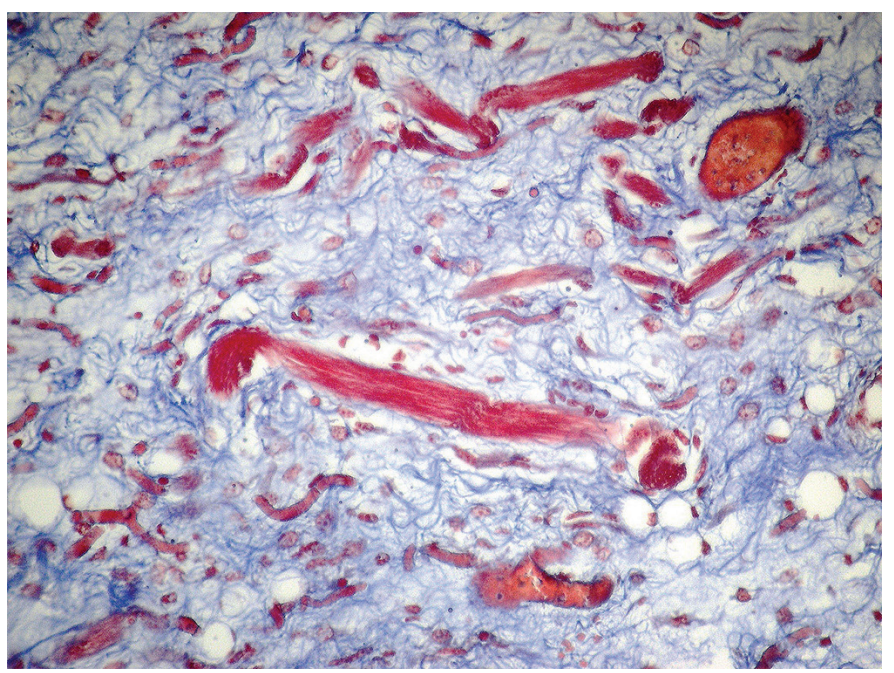

Fig.3. Skeletal muscle. Few atrophic muscle fibers (stain red) within abundant fibroadipose connective tissue (stain blue). Masson Trichrome, bar $=50 \mu \mathrm{m}$.

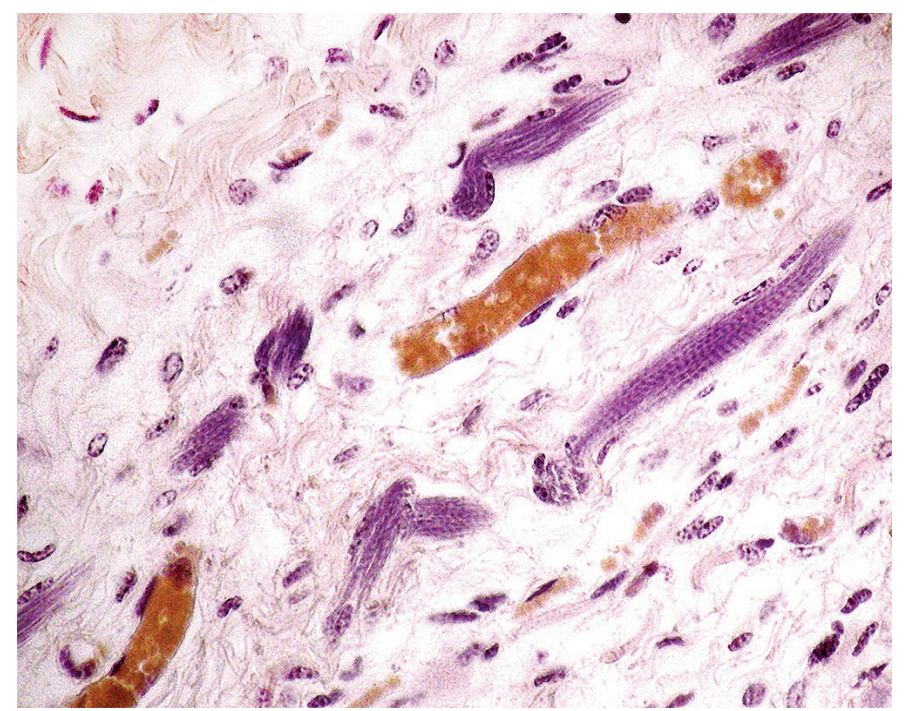

Fig.4. Sarcoplasmic cross-striations of muscle fibers (stain blue). Phosphotungstic Acid Hematoxylin, obj.40x. and fetal akinesia at this stage produces joint stiffness, muscle contractures, or arthrogryposis (Hall 2014, Kowalczyk \& Feluś 2016). Absence of fetal mobility may be due to fetal (neurogenic or myogenic) or maternal (infections, drugs, trauma) abnormalities (Hall 2014, Agerholm et al. 2016, Kowalczyk \& Feluś 2016).

In cattle, arthrogryposis with hydranencephaly, porencephaly and cerebellar hypoplasia is associated with teratogenic viral infection (Akabane virus, Bovine viral diarrhea virus, Border disease virus, Schmallenberg virus, Bluetongue virus). Viral infection was ruled out since there were no macroscopic or histological lesions in the CNS (Kessell et al. 2011, Bayrou et al. 2014, Agerholm et al. 2015, Kirkland 2015, Peperkamp et al. 2015, Cantile \& Youssef 2016). A toxic origin was also rejected. Lupinus sp., Conium maculatum, Nicotiana glauca, when ingested during days 40 to 80 of the pregnancy, can cause arthrogryposis, but these plant species were not present on the farm, and no clinical signs of toxicosis were observed in pregnant cows (Green et al. 2015). Viral infections or toxins that affect the nervous system are generally epidemic, which did not happen in this case.

The presence of lesions in the muscular system, with their absence in the encephalon and spinal cord, suggest that AMC in black AA may be due to a failure in the NMJ. Similarly, Agerholm et al. (2016) described a familial arthrogryposis multiplex congenita in Red dairy cattle, with complete lipomatous muscular atrophy, an absence of lesions in the brain and a normal number of motor neurons in the spinal cord. This neuromuscular disorder is due to a deletion in the CHRNB1 gene that is of essential importance in the NMJ (Agerholm et al. 2016).

In this case, the AA herd had no previous record of births of animals with congenital malformations, and imported semen was used for the first time. So, it can be established that at least two cows, as well as imported semen from Argentina, are carriers of AMC. So, it can be established that AM-Carriers are present in the AA breed in Uruguay and Argentina and that the disease may occur in both countries.

Reporting of congenital malformations to diagnostic laboratories, along with surveillance programs to identify carriers

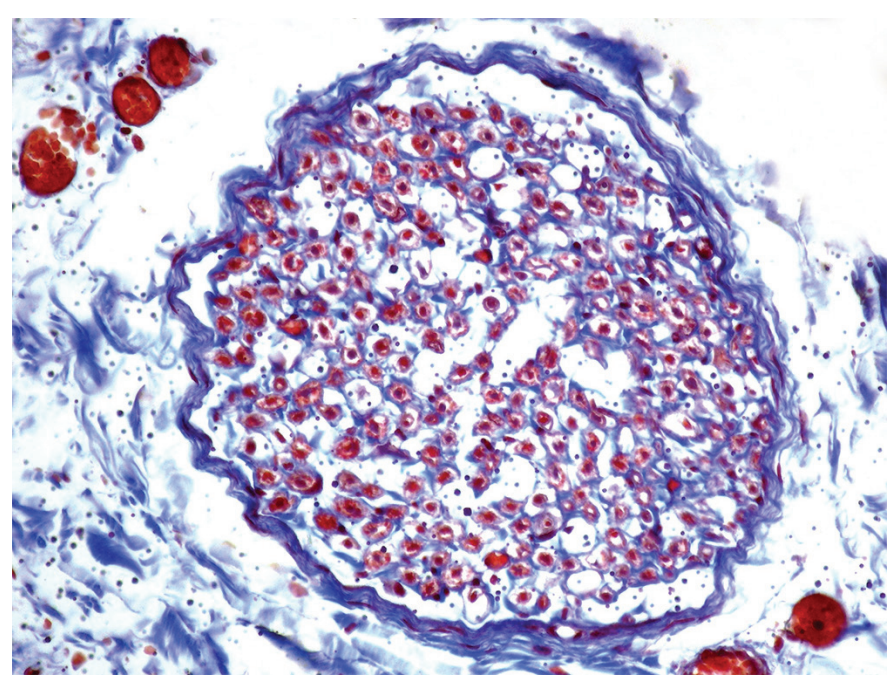

Fig.5. Light microscopy image of an intramuscular nerve. Normal appearance of myelin is seen; myelin sheaths (stain purple-red), collagen fibers (stain blue). Masson Trichrome, obj.40x. 
(DNA tests) of undesirable traits, would help to prevent the spread of hereditary diseases (Jolly \& Windsor 2010, Windsor et al. 2011). The use of genetic screening is much more effective when applied to all pedigree animals of the breed.

\section{CONCLUSIONS}

This seems to be the first study demonstrating the existence of arthrogryposis multiplex congenita in Aberdeen Angus cattle in Uruguay.

The presence of lesions limited to the muscular system, with the absence of pathological findings in the central nervous systems and intramuscular nerves could establish that the disease in this breed is due to a failure in the neuromuscular junction (NMJ).

\section{REFERENCES}

Agerholm J.S., Hewicker-Trautwein M., Peperkamp K. \& Windsor P.A. 2015. Virus-induced congenital malformations in cattle. Acta Vet. Scand. 57(1):54. <http://dx.doi.org/10.1186/s13028-015-0145-8> <PMid:26399846>

Agerholm J.S., McEvoy F.J., Menzi F., Jagannathan V. \& Drögemüller C. 2016. CHRNB1 frameshift mutation is associated with familial arthrogryposis multiplex congenita in Red dairy cattle. BMC Genomics 17(1):479. <http://dx.doi.org/10.1186/s12864-016-2832-x> <PMid:27364156>

Bayrou C., Garigliany M.M., Sarlet M., Sartelet A., Cassart D. \& Desmecht D. 2014. Natural intrauterine infection with Schmallenberg virus in malformed newborn calves. Emerg. Infect. Dis. 20(8):1327-1330. <http://dx.doi.org/10.3201/eid2008.121890> <PMid:25062351>

Beever J.E. \& Marron B.M. 2011. Screening for arthrogryposis multiplex in bovines. United States patent 20110151440 A1, Agrigenomics Inc., Mansfield, IL.

Burgess R.W., Nguyen Q.T., Son Y.J., Lichtman J.W. \& Sanes J.R. 1999. Alternatively spliced isoforms of nerve- and muscle-derived agrin: their roles at the neuromuscular junction. Neuron 23(1):33-44. <http://dx.doi.org/10.1016/S0896-6273(00)80751-5>

Cantile C. \& Youssef S. 2016. Nervous system, p.250-406. In: Maxie M.G. (Ed.), Jubb, Kennedy and Palmer's Pathology of Domestic Animals. Vol.1. 6th ed. Elsevier, St. Louis, MO.

Charlier C., Coppieters W., Rollin F., Desmecht D., Agerholm J.S., Cambisano N., Carta E., Dardano S., Dive M., Fasquelle C., Frennet J.C., Hanset R., Hubin X., Jorgensen C., Karim L., Kent M., Harvey K., Pearce B.R., Simon P., Tama N., Nie H., Vandeputte S., Lien S., Longeri M., Fredholm M., Harvey R.J. \& Georges M. 2008. Highly effective SNP-based association mapping and management of recessive defects in livestock. Nat. Genet. 40(4):449-454. <http://dx.doi.org/10.1038/ng.96> <PMid:18344998>

Cooper B.J. \& Valentine B.A. 2016. Muscle and tendon, p.164-249. In: Maxie M.G. (Ed.), Jubb, Kennedy and Palmer's Pathology of Domestic Animals. Vol.1. 6th ed. Elsevier, St. Louis, MO.

Craig L.E., Dittmer K.E. \& Thompson K.G. 2016. Bones and joints, p.16-163. In: Maxie M.G. (Ed.), Jubb, Kennedy and Palmer's Pathology of Domestic Animals. Vol.1. 6th ed. Elsevier, St. Louis, MO.

DIEA 2003. La ganadería en Uruguay, contribución a su conocimiento. Ministerio de Ganadería, Agricultura y Pesca (MGAP), Montevideo, Uruguay. Available at <http://www.mgap.gub.uy/portal/page.aspx?2,diea,diea-pub-ganaderia>

Dutra F. 2016. Monstruosidades y enfermedades genéticas de los bovinos en Uruguay, su importancia y significado. XLIV Jornadas Uruguayas de Buiatría, Paysandú, Uruguay, p.41-50.

Dutra F., Castro A., Mayol C. \& Quinteros C. 2011. Cardiomiopatía congénita asociada al pelaje crespo en terneros Polled Hereford en Uruguay. Veterinaria, Montevideo, 47(183):15-21.

Dutra F., Quintans G. \& Banchero G. 2007. Lesions in the central nervous system associated with perinatal lamb mortality. Aust. Vet. J. 85(10):405-413. <http://dx.doi.org/10.1111/j.1751-0813.2007.00205.x><PMid:17903128>
Dutra F., Quinteros C., Briano C \& Romero A. 2017. Enfermedades hereditarias. Arch. Vet. Este 20:2-7.

Dutra F., Romero A., Quinteros C. \& Kelly L. 2015. Maple Syrup Urine Disease (MSUD) en terneros Polled Hereford y cruzas Polled Hereford x Shorthorn en Uruguay. Veterinaria, Montevideo, 51(200):14-25.

Green B.T., Panter K.E., Lee S.T., Welch K.D., Pfister J.A., Gardner D.R., Stegelmeier B.L. \& Davis T.Z. 2015. Differences between Angus and Holstein cattle in the Lupinus leucophyllus induced inhibition of fetal activity. Toxicon 106:1-6. <http://dx.doi.org/10.1016/j.toxicon.2015.08.020>

Hall J.G. 2014. Arthrogryposis (multiple congenital contractures): diagnostic approach to etiology, classification, genetics, and general principles. Eur. J. Med. Genet. 57(8):464-472. <http://dx.doi.org/10.1016/j.ejmg.2014.03.008> <PMid:24704792>

Jolly R.D. \& Windsor P.A 2010. Genetic disease of cattle, p.759-777. In: Parkinson T.J., Vermunt J.J., Malmo J. \& Laven R. (Eds), Diseases of Cattle in Australasia. Massey University Press, Auckland.

Kaiser L. 2009. The gene gurus have been busy this decade: recessive defect, mutations and DNA-based tests. Periodical, p.1-4. Available at $<$ http://kaisercattle.com/pdf/Deadcows.pdf >

Kelly L., Dutra F., Llambí S., Rivero R., Moraes J., Trenchi G., D’Agosto S., Peraza P., Ravagnolo 0. \& Dalla Rizza M. 2012. Diagnóstico molecular de enfermedades hereditarias bovinas en el Uruguay. Veterinaria, Montevideo, 48(188):3-11.

Kessell A.E., Finnie J. \& Windsor P. 2011. Neurological diseases of ruminant livestock in Australia. IV: viral infections. Aust. Vet. J. 89(9):331-337. <http://dx.doi.org/10.1111/j.1751-0813.2011.00817.x><PMid:21864304>

Kirkland P.D. 2015. Akabane virus infection. Rev. Sci. Tech. 34(2):403-410. <http://dx.doi.org/10.20506/rst.34.2.2366><PMid:26601444>

Kowalczyk B \& Feluś J. 2016. Arthrogryposis: an update on clinical aspects, etiology, and treatment strategies. Arch. Med. Sci. 12(1):10-24 <http://dx.doi.org/10.5114/aoms.2016.57578> <PMid:26925114>

Maselli R.A., Fernandez J.M., Arredondo J., Navarro C., Ngo M., Beeson D., Cagney O., Williams D.C., Wollmann R.L., Yarov-Yarovoy V. \& Ferns M.J. 2012. LG2 agrin mutation causing severe congenital myasthenic syndrome mimics functional characteristics of non-neural (z-) agrin. Hum. Genet. 131(7):1123-1135 <http://dx.doi.org/10.1007/s00439-011-1132-4> <PMid:22205389>

OMIA 2020. OMIA 002135-9913: arthrogryposis multiplex congenita, AGRN-related in Bos taurus. Online Mendelian Inheritance in Animals, Sydney School of Veterinary Science, The University of Sidney, New South Wales, Sidney. Available at <https://www.omia.org/OMIA002135/9913/> Accessed on Jan. 30, 2020.

Peperkamp N.H., Luttikholt S.J., Dijkman R., Vos J.H., Junker K., Greijdanus S., Roumen M.P., van Garderen E., Meertens N., Van Maanen C., Lievaart K., Van Wuyckhuise L. \& Wouda W. 2015. Ovine and bovine congenital abnormalities associated with intrauterine infection with Schmallenberg virus. Vet. Pathol. 52(6):1057-1066. <http://dx.doi.org/10.1177/0300985814560231> $<$ PMid:25428409>

Shupe J.L., James L.F., Balls L.D., Binns W. \& Keeler R.F. 1967. A probable hereditary skeletal deformity in Hereford cattle. J. Hered. 58(6):311-313 <http://dx.doi.org/10.1093/oxfordjournals.jhered.a107627><PMid:5590155>

Whitlock B.K. 2010. Heritable birth defects in cattle. Proceedings Applied Reproductive Strategies in Beef Cattle, Nashville, TN, p.146-153.

Windsor P.A. \& Agerholm J.S. 2009. Review inherited diseases of Australian Holstein-Friesian cattle. Aust. Vet. J. 87(5):193-199. <http://dx.doi.org/10.1111/j.1751-0813.2009.00422.x><PMid:19382928>

Windsor P.A., Kessell A.E. \& Finnie J.W. 2011. Neurological diseases of ruminant livestock in Australia. V: congenital neurogenetic disorders of cattle. Aust. Vet J. 89(10):394-401. <http://dx.doi.org/10.1111/j.1751-0813.2011.00826.x> 